\title{
Intake and digestibility of sorghum (Sorghum bicolor, L. Moench) silages with different tannin contents in sheep ${ }^{1}$
}

\author{
Alex de Matos Teixeira², Gabriel de Oliveira Ribeiro Junior², Frederico Osório Velasco², Wilson \\ Gonçalves de Faria Júnior ${ }^{2}$, Norberto Mario Rodriguez ${ }^{2}$, José Avelino Santos Rodrigues ${ }^{3}$, \\ Tim McAllister ${ }^{4}$, Lúcio Carlos Gonçalves ${ }^{2}$
}

\footnotetext{
${ }^{1}$ Research financed by FAPEMIG, EMBRAPA, DZO-EVIUFMG and Pró-Reitoria de Pesquisa da UFMG.

${ }^{2}$ Escola de Veterinária, Universidade Federal de Minas Gerais, Belo Horizonte, MG, Brasil.

${ }^{3}$ Embrapa Milho e Sorgo, Sete Lagoas, MG, Brasil.

${ }^{4}$ Agriculture and Agri-food Canada, Lethbridge Research Centre, Lethbridge, Alberta, Canada.
}

\begin{abstract}
The purpose of this study was to evaluate the voluntary intake and digestibility of three sorghum (Sorghum bicolor, L. Moench) hybrid silages in sheep. The hybrids used were H1 - BRS 655 (CMSXS 222 A $\times$ CMSXS 235 R), with tannin; H2 - (ATF54 A × CMSXS 235 R), without tannin; and H3 - BRS 610 (CMSXS 232 A × CMSXS 234 R), without tannin. The intake and digestibility of dry matter (DM), gross energy (GE), neutral detergent fiber (NDF), acid detergent fiber (ADF) and crude protein $(\mathrm{CP})$ were measured. Eighteen crossbred sheep weighing $59.4 \mathrm{~kg}( \pm 8.3)$ were used in the trial. A completely randomized design with three treatments (hybrids) and six repetitions (sheep) was used. There were no differences in the DM intake or apparent digestibility among the hybrids. Silage of hybrid BRS 610 displayed higher digestibility coefficients for CP, NDF, ADF, and GE compared with the other silages, which did not differ from each other. The neutral detergent fiber, ADF and digestible energy (DE) intakes were similar among the hybrids silages. All of the hybrids resulted in a positive $\mathrm{N}$ balance in sheep. The levels of DE were superior in hybrid silage BRS 610 in comparison with the other hybrids. Sorghum hybrid BRS 610 silage exhibited superior nutritional value compared with the other hybrids, which is most likely in part due to the absence of tannins. Sorghum silage made with hybrid BRS 610 (CMSXS $232 \mathrm{~A} \times$ CMSXS $234 \mathrm{R}$ ) presents superior gross energy, crude protein, neutral detergent fiber and acid detergent fiber digestibility coefficients, as well as greater digestible energy levels than BRS 655 (CMSXS $222 \mathrm{~A} \times$ CMSXS $235 \mathrm{R})$ and (ATF54 A × CMSXS $235 \mathrm{R})$.
\end{abstract}

Key Words: forage preservation, nitrogen balance, nutritional value, ram, sorghum hybrid

\section{Introduction}

Maize and sorghum are the most widely used tropical cereal crops for silage because of their high yields of dry matter (DM) (Fribourg, 1995; Rooney et al., 2007), low buffering capacity and high water-soluble carbohydrate (WSC) content (Stuart, 1984; McDonald et al., 1991).

Under arid and semiarid conditions and at high elevations, sorghum silage (Sorghum bicolor, L. Moench) is favored over corn silage as forage for ruminants due to its lower requirement for soil fertility, lower production costs, possibility of a second cut, and greater resistance to drought and high temperatures. Furthermore, in areas with better rainfall distribution, this culture has shown good adaptability as a second crop (Pedreira et al., 2003). For these reasons, the importance of sorghum as a forage crop is growing in many regions of the world. The sorghum crop is well adapted to hot climates, such as in Sudan (Ibrahim, 1999) and Brazil (Neumann et al., 2002), and now, due to higher mean temperatures, this crop is also being used as a forage for more Northern latitudes, such as in southern Canada (McCaughey et al., 1996).

Various hybrids and varieties of sorghum differ in their dry matter (DM), water-soluble carbohydrates (WSC), protein, neutral detergent fiber (NDF), acid detergent fiber (ADF), and acid detergent lignin (ADL) contents (Pedersen et al., 1982; Neumann et al., 2002; Carmi et al., 2005). Consequently, considerable differences in DM and NDF digestibility among sorghum silages have been reported (Ashbell et al., 1999; Miron et al., 2005; Machado et al., 2011).

The Brazilian Agricultural Research Corporation (Embrapa) has been developing sorghum hybrids for silage that exhibit resistance to lodging and various diseases, while producing a higher DM yield and possessing a more desirable nutritional profile for ruminants. Sorghum hybrids with tannin may play an important role in sorghum resistance to bird attacks (Beta et al., 2000).

Tannins are defined as naturally occurring phenolic compounds with high molecular weights and with the ability to bind to macromolecules, such as proteins, structural 
carbohydrates and starches, thereby decreasing their ruminal degradation (McSweeney et al., 2001; Silanikove et al., 2001). Tannins are divided into two major groups: hydrolyzable and condensed tannins. The polyphenols that are found in sorghum are condensed tannins (Jansman, 1993).

Reduction in dry matter intake and in the digestion of protein and fiber is an adverse effect often associated with tannins (Schofield et al., 2001; Makkar, 2003). However, the presence of moderate levels of condensed tannins in the rumen is related to the protection of dietary protein against degradation by ruminal microorganisms, which increases the flux of dietary protein to be absorbed in the intestines (Min et al., 2003). More recently, condensed tannins have also been linked to reduction in ruminal methane emission (Woodward et al., 2001; Makkar, 2003).

The presence of tannins during the silage fermentation process can protect forage proteins from degradation (Salawu et al., 1999; Kondo et al., 2004) by inhibiting plant and microbial enzymes and/or by forming complexes with proteins (Makkar, 2003). This observation is supported by a reduction of ammonia $\mathrm{N}$, which is usually observed in silages containing tannins (Gonçalves et al., 1999; Adesogan and Salawu, 2002). According to Cummins (1971) and Oliveira et al. (2009), the fermentation process can also decrease the levels of condensed tannins in sorghum silages, and, because of this decrease, animals may not be negatively affected by high tannin sorghum silages. This reduction in tannin levels is most likely due to tannin inactivation by the low $\mathrm{pH}$ and anaerobic conditions that are usually present in silages (McSweeney et al., 1999) and due to tannin degradation to low-molecular weight polyphenols (Kondo et al., 2004).

The objective of this study was to determine the nutritional value of three sorghum (Sorghum bicolor, L. Moench) hybrid silages that differed in tannin content, which were developed by the genetic improvement program of Embrapa, through intake and apparent digestibility in sheep.

\section{Material and Methods}

Three stem dry hybrid forage sorghums, which were developed by the genetic improvement program of Embrapa, were used: H1 - BRS655 (CMSXS 222A × CMSXS 235R), with tannin; H2 - (ATF54A × CMSXS235 R), without tannin; and H3 - BRS610 (CMSXS 232A $\times$ CMSXS 234R), without tannin. Hybrid H2 is extremely similar to BRS610; however, hybrid $\mathrm{H} 2$ has a smaller seed size. Sorghum hybrids with total phenol levels that were higher than $0.75 \%$ of the DM, which was analyzed by the Prussian blue method, were considered with tannin, and the hybrids with levels that were lower than $0.75 \%$ were considered without tannin. This level is used by Embrapa to classify their new sorghum hybrids. The hybrids were grown, harvested and ensiled on the premises of Embrapa Milho e Sorgo, Sete Lagoas, Minas Gerais, Brazil. The sorghum hybrids were planted with $0.7 \mathrm{~m}$ space between rows, at a density of 120,000 plants/ha. All hybrids were harvested at the dough stage (100-108 d) using a forage harvester and were chopped to a theoretical length of $0.5-1.5 \mathrm{~cm}$. Forages were immediately ensiled in plastic bags within 200-L steel barrels, which were compacted by trampling, and sealed.

An in vivo study was conducted on the premises of the Department of Animal Science in the Veterinary School at Universidade Federal de Minas Gerais (UFMG), Belo Horizonte, Minas Gerais, Brazil, at the Animal Metabolism and Calorimetry Laboratory. All procedures and protocols that were used in this experiment were approved by the UFMG Ethics Committee on Animal Experimentation (CETEA Protocol No. 043/09). Adult crossbred Santa Inês woolless rams $(\mathrm{n}=18)$, which weighed an average of $59.4 \mathrm{~kg}( \pm 8.3)$, were used. The sheep were randomly housed in individual metabolic cages with slatted floors. The cages had funnels that were attached to the wooden floors, beneath which there were plastic boxes (for feces collection) and screen-topped plastic buckets (for urine collection). To avoid urinary nitrogen loss by volatilization and/or decomposition, $100 \mathrm{~mL}$ of $2 \mathrm{~N} \mathrm{HCl}$ were added to the urine collection buckets daily. After a $21 \mathrm{~d}$ adaptation period, in which the sheep were acclimatized to the diets and cages, total collection was performed at $5 \mathrm{~d}$. Sheep weights were measured at the beginning and at the end of the adaptation and experimental periods.

Sorghum silages were fed twice daily $(07.00$ and $17.00 \mathrm{~h})$ and provided ad libitum throughout the experiment. Water and a commercial mineral mixture were also provided $a d$ libitum. Silage, orts and feces were weighed daily, and a portion $(20 \%)$ from each animal was retained for further analysis. Urine was collected once daily $(07.00 \mathrm{~h})$, with a $10 \%$ aliquot being stored for further analysis. Composite samples of orts, feces, urine, and silages of each animal were stored at $-17^{\circ} \mathrm{C}$ until analyzed.

Samples of feces, silage that was offered and orts were thawed at room temperature and dried in a forced air oven at $55{ }^{\circ} \mathrm{C}$ for $72 \mathrm{~h}$. The dried samples were ground in a Wiley stationary mill through a $1 \mathrm{~mm}$ screen and stored in polyethylene containers with lids. Samples were analyzed in duplicate for the $\mathrm{DM}$ at $105{ }^{\circ} \mathrm{C}$ and ether extract (EE) (AOAC, 1980), crude protein (CP) and nitrogen content (N) by the Kjeldahl method (AOAC, 1995); NDF, ADF and lignin by the sequential method of Van Soest et al. (1991); 
and gross energy (GE) by combustion in an adiabatic bomb calorimeter PARR model 2081 (AOAC, 1995). The gross energy content of the urine was determined by bomb calorimetry, and $\mathrm{N}$ and $\mathrm{CP}$ were determined as described above. Only samples of the offered silage were examined for levels of neutral detergent insoluble nitrogen (NDIN) and acid detergent insoluble nitrogen (ADIN) (Van Soest et al., 1991). The in vitro DM digestibility (IVDMD) was evaluated according to the two-stage procedure that was described by Tilley and Terry (1963), adapted by Holden (1999) using a rumen simulator Daisy II ANKOM ${ }^{\circledR}$. Extracts of fresh silage were obtained with a hydraulic press for the determination of the ammonia nitrogen content $\left[\mathrm{NH}_{3}-\mathrm{N}\right.$ $(\%$ of total $\mathrm{N})]$, as well as acetic, propionic, butyric and lactic acids, by gas chromatography (GC-17 Shimadzu gas chromatograph using a Nukol capillary column). Samples were $(10 \mathrm{~mL})$ acidified with $2 \mathrm{~mL}$ of metaphosphoric acid $(0.25 ; \mathrm{w} / \mathrm{v})$ and frozen at $-20{ }^{\circ} \mathrm{C}$ until analyzed for organic acids. Ammonia-N was determined by the Kjeldahl method, with the volatile $\mathrm{N}$ fraction distilled by heating the solution at $\mathrm{pH}>7$ with $\mathrm{MgO}$.

The voluntary intake of nutrients on the DM basis of sorghum silages was determined by the difference between the silage that was offered to rams and orts, and the apparent digestibility values were obtained from the total collection of feces. To assess the nutrient digestibility (ND), the following equation, described by Schneider and Flatt (1975), was used:

$$
\mathrm{ND}=\frac{(\text { nutrient intake }- \text { nutrient excretion })}{\text { Nutrient intake }} \times 100
$$

The experimental design that was adopted was completely randomized with three treatments and six repetitions. The statistical analysis was performed using the statistical model: $\mathrm{Y}_{\mathrm{ij}}=\mathrm{T}+\mu_{\mathrm{i}}+€_{\mathrm{ij}}$, in which $\mathrm{Y}_{\mathrm{ij}}=$ observation " $j$ " in the hybrid " $i$ "; $\mu=$ overall mean; $T_{i}=$ effect of hybrid $(\mathrm{i}=1,2,3)$; and $€_{\mathrm{ij}}=$ experimental error. The obtained data were subjected to variance analysis using the SAS software package for statistics (Statistical Analysis System, version 6.12), with the means compared by Student-Newman-Keuls test (SNK) at $5 \%$ probability $(\mathrm{P}<0.05)$.

\section{Results and Discussion}

According to Demarquilly and Dulphy (1977), the optimal DM content of silage to avoid seepage losses, undesirable microorganism fermentation and reduced intake is 27 to $38 \%$. The silage hybrids $\mathrm{H} 1$ and $\mathrm{H} 2$ had DM contents of 26.01 and $26.58 \%$, respectively, and were close to the minimum DM content that was proposed by Demarquilly and Dulphy (1977) to obtain high-quality silage, whereas the DM content of silage hybrid H3 (BRS 610 ) was $18.58 \%$, which was considered low (Table 1). A previous study by Faria Jr et al. (2011) evaluated the hybrid BRS 610 at different maturity stages and found that the DM content varied from 18.36 to $29.84 \%$ between milky and farinaceous stages. The daily rainfall before the ensiling of hybrid BRS610 is most likely the cause of its low DM content. The crude protein content ranged from 7.13 to $8.17 \%$ of the DM, which is within the range of 6 to $8 \%$ of the DM, which is the minimum recommended by Van Soest (1994) for proper rumen fermentation.

Neutral detergent fiber and ADF values ranged from 58.64 to $59.26 \%$ and 36.41 to $38.87 \%$, respectively. The IVDMD were $59.43,62.56$ and $59.22 \%$ for the hybrids $\mathrm{H} 1, \mathrm{H} 2$ and $\mathrm{H} 3$, respectively. Ether extract values were 3.96, 4.79, and $6.29 \%$ for the hybrids $\mathrm{H} 1, \mathrm{H} 2$ and $\mathrm{H} 3$, respectively (Table 1). All sorghum silage hybrids presented good fermentation, with low levels of ammonia-N $(<10 \%)$. According to Lavezzo (1994), well-preserved silages have $\mathrm{pH}$ between 3.8 and 4.2. All of the silages that were tested in this work were within this $\mathrm{pH}$ range.

There were no differences among the hybrids for DM intake and $\mathrm{DM}$ digestibility $(\mathrm{P}>0.05$; Table 2$)$. The $\mathrm{DM}$ intake values were higher than that suggested by AFRC (1993) $\left(51.02 \mathrm{~g} / \mathrm{wt}^{0.75} / \mathrm{d}\right)$ and NRC (1985) $\left(53.19 \mathrm{~g} / \mathrm{wt}^{0.75} / \mathrm{d}\right)$ for adult sheep on a maintenance diet. Reduced DM digestion, which is associated with tannin concentrations in sorghum silages, has been observed in vitro (Cummins, 1971; Arora et al., 1975; Montgomery et al., 1986) and in vivo

\begin{tabular}{|c|c|c|c|}
\hline \multirow[b]{2}{*}{ Item $(\%$ of DM) } & \multicolumn{3}{|c|}{ Hybrids } \\
\hline & $\begin{array}{c}\mathrm{H} 1 \\
(\mathrm{BRS} 655)\end{array}$ & $\begin{array}{c}\mathrm{H} 2 \\
(\mathrm{ATF} 54 \mathrm{~A} \times \\
\text { CMSXS 235 R) }\end{array}$ & $\begin{array}{c}\mathrm{H} 3 \\
(\mathrm{BRS} 610)\end{array}$ \\
\hline Dry matter & 26.01 & 26.58 & 18.58 \\
\hline Crude protein & 7.54 & 8.17 & 7.13 \\
\hline Ether extract & 3.96 & 4.79 & 6.29 \\
\hline Neutral detergent fiber & 59.26 & 59.20 & 58.64 \\
\hline Acid detergent fiber & 36.41 & 38.18 & 38.87 \\
\hline Lignin & 6.95 & 6.91 & 6.75 \\
\hline In vitro $\mathrm{DM}$ digestibility & 59.43 & 62.56 & 59.22 \\
\hline NDIN $^{1}$ & 71.76 & 71.21 & 53.17 \\
\hline $\mathrm{ADIN}^{1}$ & 52.21 & 57.96 & 36.58 \\
\hline $\mathrm{NH}_{3}-\mathrm{N}^{1}$ & 4.50 & 3.88 & 2.73 \\
\hline $\mathrm{pH}$ & 4.21 & 3.91 & 3.69 \\
\hline Lactate & 5.41 & 6.94 & 9.34 \\
\hline Butyrate & 1.27 & 0.01 & 0.12 \\
\hline Acetate & 1.58 & 1.72 & 2.72 \\
\hline Propionate & 0.06 & 0.02 & 0.02 \\
\hline
\end{tabular}

Table 1- Chemical composition of three sorghum hybrid silages

${ }^{1}$ The results are expressed as percentage of total nitrogen.

NDIN - neutral detergent insoluble nitrogen; ADIN - acid detergent insoluble nitrogen. 
(Ben-Ghedalia and Tagari, 1977). However, more recently, Rodriguez et al. (1999) and Carneiro et al. (2006), who worked in vitro, and Oliveira et al. (2007) and Machado et al. (2011), who worked in vivo, similarly to the present study, did not find any effect of tannin levels in sorghum silages on DM digestibility. The absence of tannin effects on DM digestibility in the recently performed studies is most likely due to the lower tannin concentrations of the new bird resistant sorghum hybrids that were evaluated.

The $\mathrm{CP}$ intakes were similar for hybrids $\mathrm{H} 1$ and $\mathrm{H} 3(\mathrm{P}>0.05)$, and the values were lower than hybrid $\mathrm{H} 2$ $(\mathrm{P}<0.05)$. Hybrid $\mathrm{H} 3$ exhibited higher $\mathrm{CP}$ digestibility $(\mathrm{P}<0.05)$ when compared with the other hybrids (Table 2$)$. Changes in the $\mathrm{CP}$ digestibility of sorghum silage can be attributed, in part, to the capacity of tannins to form complexes with organic compounds, such as proteins, that reduce their availability in the gastrointestinal tract, which can be demonstrated by comparing the H1 (with tannin) and H3 (no tannin) hybrids. However, the hybrid H2 (no tannin) presented $\mathrm{CP}$ digestibility values that were similar $(\mathrm{P}>0.05)$ to hybrid $\mathrm{H} 1$ (with tannin) and that were lower than hybrid H3 (no tannin). This unexpected result may be associated with a higher percentage of sorghum grains present in the feces of the animal receiving silage of hybrid $\mathrm{H} 2$, which is related to higher nitrogen contents in feces. This higher quantity of sorghum grains in the feces of the rams that received silage of hybrid $\mathrm{H} 2$ is most likely due to its smaller seed size compared with the others.
The values of $\mathrm{N}$ intake were similar among the hybrids $(\mathrm{P}>0.05)$. For the fecal $\mathrm{N}$, the hybrid $\mathrm{H} 3$ had the lowest value $(\mathrm{P}<0.05)$, followed by the other hybrids, which did not differ between themselves ( $\mathrm{P}>0.05$; Table 2). Such a result justifies the behavior that was observed for the $\mathrm{CP}$ digestibility. In contrast, the urinary $\mathrm{N}$ was higher for the hybrid H3 $(\mathrm{P}<0.05)$. Despite the low $\mathrm{CP}$ level of the diets, all treatments showed positive values for retained $\mathrm{N}$, which indicated that there was no protein loss by the animals. For the ratio between retained $\mathrm{N}$ and ingested $\mathrm{N}$ (retN/ingN), there were no differences among the hybrids $(\mathrm{P}>0.05)$. Nitrogen balance is a good indicator of animal protein metabolism, which is more efficient than the intake and digestibility of protein for determining whether there was loss of protein by the organism.

There were no differences in NDF and ADF intakes $(\mathrm{P}>0.05)$. The highest NDF digestibility $(\mathrm{P}<0.05)$ was observed for the hybrid H3 (BRS 610), whereas the other treatments were similar $(\mathrm{P}>0.05$; Table 2$)$. The ADF digestibility showed a similar pattern to that of the NDF digestibility, which ranged from $42.02 \%$ to $51.99 \%$. Satter and Slyter (1974) observed that the growth of cellulolitic bacteria was limited at ammonia- $\mathrm{N}$ concentrations of rumen fluid lower than $5.0 \mathrm{mg} \mathrm{NH}-\mathrm{N} / 100 \mathrm{~mL}$, which compromised fiber digestibility. The lower $\mathrm{CP}$ digestibility of sorghum silages from hybrids $\mathrm{H} 1$ and $\mathrm{H} 2$ might have promoted ammonia- $\mathrm{N}$ concentrations in rumen fluid that were lower than $5.0 \mathrm{mg} \mathrm{NH}_{3}-\mathrm{N} / 100 \mathrm{~mL}$, which affected the

Table 2 - Intake, digestibility, nitrogen balance and silage energy of three sorghum hybrid silages that were fed ad libitum to sheep

\begin{tabular}{|c|c|c|c|c|}
\hline \multirow[b]{2}{*}{ Item $(\%$ of DM) } & \multicolumn{3}{|c|}{ Hybrids } & \multirow[b]{2}{*}{$\mathrm{CV}(\%)$} \\
\hline & $\begin{array}{c}\mathrm{H} 1 \\
(\mathrm{BRS} 655)\end{array}$ & $\begin{array}{c}\mathrm{H} 2 \\
(\mathrm{ATF} 54 \mathrm{~A} \times \mathrm{CMSXS} 235 \mathrm{R})\end{array}$ & $\begin{array}{c}\mathrm{H} 3 \\
(\mathrm{BRS} 610)\end{array}$ & \\
\hline \multicolumn{5}{|l|}{ Intake } \\
\hline Dry matter $\left(\mathrm{g} / \mathrm{wt}^{0.75} / \mathrm{d}\right)$ & 60.25 & 62.09 & 58.94 & 9.65 \\
\hline Crude protein $\left(\mathrm{g} / \mathrm{wt}^{0.75} / \mathrm{d}\right)$ & $4.58 b$ & $5.21 \mathrm{a}$ & $4.14 b$ & 9.78 \\
\hline Neutral detergent fiber $\left(\mathrm{g} / \mathrm{wt}^{0.75} / \mathrm{d}\right)$ & 35.50 & 36.47 & 35.16 & 17.55 \\
\hline Acid detergent fiber $\left(\mathrm{g} / \mathrm{wt}^{0.75} / \mathrm{d}\right)$ & 21.98 & 23.64 & 23.44 & 17.28 \\
\hline Gross energy $\left(\mathrm{kcal} / \mathrm{wt}^{0.75} / \mathrm{d}\right)$ & 244.32 & 250.12 & 240.99 & 9.59 \\
\hline Digestible energy $\left(\mathrm{kcal} / \mathrm{wt}^{0.75} / \mathrm{d}\right)$ & 131.52 & 133.90 & 143.44 & 14.25 \\
\hline \multicolumn{5}{|l|}{ Digestibility (\%) } \\
\hline Dry matter & 55.52 & 55.22 & 58.20 & 5.36 \\
\hline Crude protein & $32.75 b$ & $32.89 b$ & $47.28 \mathrm{a}$ & 17.26 \\
\hline Neutral detergent fiber & $45.56 b$ & $44.52 b$ & $50.85 a$ & 7.70 \\
\hline Acid detergent fiber & $42.02 b$ & $46.20 \mathrm{~b}$ & $51.99 \mathrm{a}$ & 9.66 \\
\hline Gross energy & $53.69 b$ & $53.40 \mathrm{~b}$ & $59.57 \mathrm{a}$ & 7.66 \\
\hline \multicolumn{5}{|l|}{ Nitrogen } \\
\hline $\mathrm{N}$ intake $(\mathrm{g} / \mathrm{d})$ & 15.41 & 17.31 & 14.92 & 17.25 \\
\hline Fecal N (g/d) & $10.37 \mathrm{a}$ & $11.48 \mathrm{a}$ & $7.90 \mathrm{~b}$ & 17.57 \\
\hline Urinary N (g/d) & $2.40 \mathrm{~b}$ & $2.12 b$ & $4.22 \mathrm{a}$ & 23.53 \\
\hline Retained N (g/d) & 2.64 & 3.71 & 2.81 & 40.88 \\
\hline Retained N/ingested N (\%) ${ }^{1}$ & 17.33 & 20.45 & 18.92 & 36.66 \\
\hline \multicolumn{5}{|l|}{ Silage energy } \\
\hline Digestible energy (Mcal/kg of DM) & $2.18 \mathrm{~b}$ & $2.15 b$ & $2.44 \mathrm{a}$ & 8.35 \\
\hline
\end{tabular}

${ }^{1}$ retN/ingN - ratio between retained $\mathrm{N}$ and ingested $\mathrm{N}$.

NDF - neutral detergent fiber; ADF - acid detergent fiber; DE - digestible energy; CV - coefficient of variation.

Means with different letters within rows differ $(\mathrm{P}<0.05$, SNK). 
NDF and ADF digestibilities of these silages. According to Mertens (1973), the NDF intake by sheep fed forage with NDF content between 35 and $75 \%$ is approximately $35 \mathrm{~g} / \mathrm{wt}^{0.75} / \mathrm{d}$, which is close to those values obtained in this study ( 35.16 to $\left.36.47 \mathrm{~g} / \mathrm{wt}^{0.75} / \mathrm{d}\right)$. Neutral detergent fiber is the food fraction that best correlates with DM intake by ruminants (Mertens, 1993). Thus, the NDF intake may have been a limiting factor for DM intake due to filling effect.

The gross and digestible energy intakes were similar among treatments $(\mathrm{P}>0.05)$. The $\mathrm{DE}$ intake was approximately $146.47 \mathrm{kcal} / \mathrm{wt}^{0.75} / \mathrm{d}$, which is the DE intake requirement for sheep during maintenance (NRC, 1985). The highest value $(\mathrm{P}<0.05)$ for gross energy digestibility was obtained for hybrid H3 (Table 2). The values of DE, which were expressed as Mcal $/ \mathrm{kg}$ of $\mathrm{DM}$, were similar $(\mathrm{P}>0.05)$ for silages of hybrids $\mathrm{H} 1$ and $\mathrm{H} 2$ and were lower than the hybrid $\mathrm{H} 3(\mathrm{P}<0.05)$. The determination of these parameters is important for the nutritional evaluation of feeds because these parameters indicate the efficiency with which gross energy was used. A high efficiency ratio is interesting only when accompanied by high dry matter intake.

\section{Conclusions}

Sorghum silage made with hybrid BRS 610 (CMSXS $232 \mathrm{~A} \times \mathrm{CMSXS} 234 \mathrm{R}$ ) presents superior gross energy, crude protein, neutral detergent fiber and acid detergent fiber digestibility coefficients, as well as greater digestible energy levels than BRS 655 (CMSXS $222 \mathrm{~A} \times$ CMSXS $235 \mathrm{R}$ ) and (ATF54 A $\times$ CMSXS 235 R). Therefore, sorghum hybrid BRS 610 silage presents better nutritional value compared with the other hybrids indicated for making silage.

\section{Acknowledgments}

This project was financially supported by FAPEMIG, EMBRAPA, Pró-Reitoria de Pesquisa da UFMG and DZOEV/UFMG. The authors are grateful to Krysty Munns and Sarah Meale (Agriculture and Agri-food Canada - Lethbridge Research Centre) for their help with the English translation.

\section{References}

Adesogan, A. T. and Salawu, M. B. 2002. The effect of different additives on the fermentation quality, aerobic stability and in vitro digestibility of pea/wheat bi-crop silages containing contrasting pea to wheat ratios. Grass and Forage Science $57: 25-32$.

AFRC - Agricultural and Food Research Council. 1993. Energy and protein requirements of ruminants. $\mathrm{CAB}$ International, Wallingford.
AOAC - Association Official Analytical Chemists. 1980. Official methods of analysis. 13th ed. AOAC, Washington, DC.

AOAC - Association Official Analytical Chemists. 1995. Official methods of analysis. 16th ed. AOAC International, Arlington, VA.

Arora, S. K.; Luthra, Y. P and Das, B. 1975. Locational variation in chemical composition and in vitro digestibility of forage sorghum. Journal of Agriculture and Food Chemistry 23:543-544.

Ashbell, G.; Weinberg, Z. G.; Bolsen, K. K.; Hen, Y. and Azrieli, A. 1998. The silage characteristics of two varieties of forage sorghum mixed in different proportions and at two stages of maturity. African Journal of Range and Forage Science 15:68-71.

Ben-Ghedalia, D. and Tagari, H. 1977. Digestive and ruminal metabolism of sheep fed sorghum (S. vulgare) and maize (Z. mays) silages. Nutrition Reports International 16:657-666.

Beta, T.; Rooney, L. W.; Marovatsanga, L. T. and Taylor, J. R. N. 2000. Effect of chemical treatments on polyphenols and malt quality in sorghum. Journal of Cereal Science 31:295-302.

Carmi, A.; Umiel, N.; Hagiladi, A.; Yosef, E.; Ben-Ghedalia, D. and Miron, J. 2005. Field performance of a new forage sorghum variety pnina recently developed in Israel. Journal of Science Food and Agriculture 85:2567-2573

Carneiro, H.; Souza Sobrinho, F.; Rodrigues, J. A. S.; Miranda, J. E. C. and Brum, S. S. 2006. Evaluation of sorghum silages of different genotypes with and without condensed tannins. Revista Brasileira de Milho e Sorgo 5:257-265.

Cummins, D. G. 1971. Relationship between tannin content and forage digestibility in sorghum. Agronomy Journal 63:500-502.

Demarquilly, C. and Dulphy, J. P. 1977. Effect of ensiling on feed intake and animal performance. p.53-61. In: Proceedings of International Meeting on Animal Production from Temperate Grasslands. Irish Grassland and Animal Production Association, Dublin.

Faria Jr., W. G.; Gonçalves, L. C.; Ribeiro Jr., G. O.; Carvalho, W. T. V.; Maurício, R. M.; Rodrigues, J. A. S.; Faria, W. G.; Saliba, E. O. S.; Rodriguez, N. M. and Borges, A. L. C. C. 2011. Effect of grain maturity stage on the quality of sorghum BRS-610 silages. Arquivo Brasileiro de Medicina Veterinária e Zootecnia 63:1215-1223.

Fribourg, H. A. 1995. Summer annual grasses. p.463-472. In: Forages. v.1. An introduction to grassland agriculture. Barnes, R. F.; Miller, D. A. and Nelson, C. J., eds. Iowa State University Press, Ames, IA.

Gonçalves, L. C.; Rodriguez, N. M.; Nogueira, F. S.; Borges, A. L. C. C. and Zago, C. P. 1999. Silagem de sorgo de porte baixo, com diferentes teores de tanino e de umidade no colmo. III. Quebra de compostos nitrogenados. Arquivo Brasileiro de Medicina Veterinária e Zootecnia 51:571-576.

Holden, L. A. 1999. Comparison of methods of in vitro dry matter digestibility for ten feeds. Journal of Dairy Science 82:1791-1794.

Ibrahim, Y. M. 1999. Comparative analysis of forage sorghum for best cutting time. Annals of Arid Zone 38:75-78.

Jansman, A. J. M. 1993. Tannins in feedstuffs for simple-stomached animals. Nutrition Research Reviews 6:209-236.

Kondo, M.; Kita, K. and Yokota, H. 2004. Feeding value to goats of whole-crop oat ensiled whit green tea waste. Animal Feed Science and Technology 113:71-81.

Lavezzo, W. 1994. Ensilagem do capim elefante. p.169-275. In: Anais do $10^{\circ}$ Simpósio sobre Manejo do Capim Elefante. FEALQ/ ESALQ, Piracicaba.

Machado, F. S.; Rodríguez, N. M.; Gonçalves, L. C.; Rodrigues, J. A. S.; Ribas, M. N.; Pôssas, F. P.; Guimarães Jr., R.; Jayme, D. G. and Pereira, L. G. R. 2011. Consumo e digestibilidade aparente de silagens de sorgo em diferentes estádios de maturação. Arquivo Brasileiro de Medicina Veterinária e Zootecnia 63:1470-1478.

Makkar, H. P. S. 2003. Effect and fate of tannins in ruminant animals, adaptation to tannins, and strategies to overcome detrimental effects of feeding tannin-rich feeds. Small Ruminant Research 49:241-256

McCaughey, W. P.; Therrien, M. C. and Mabon, R. 1996. Forage sorghum in southern Manitoba. Canadian Journal of Plant Science $76: 123-125$. 
McDonald, P.; Henderson, A. R. and Heron, S. 1991. The biochemistry of silage. 2nd ed. Chalcombe Publications, Marlow.

McSweeney, C. S.; Palmer, B.; Bunch, R. and Krause, D. O. 1999. Isolation and characterization of proteolytic ruminal bacteria from sheep and goats fed tannin-containing shrub legume Calliandra calothyrsus. Applied and Environmental Microbiology 65:3075-3083.

McSweeney, C. S.; Palmer, B.; McNeill, D. M. and Krause, D. O. 2001. Microbial interactions with tannins: nutritional consequences for ruminants. Animal Feed Science and Technology 91:83-93.

Mertens, D. R. 1973. Dietary fibre components: relationship to the rate and extent of ruminal digestion. Federation Proceedings 36:483-488.

Mertens, D. R. 1993. Rate and extent of digestion. Cap. 2, p.14-51. In: Quantitative aspects of ruminant digestion and metabolism. Forbes, J.M.; France, J., eds. CAB International, Londres.

Min, B. R.; Barry, T. N.; Attwood, G. T. and McNabb, W. C. 2003. The effect of condensed tannins on the nutrition and health of ruminants fed fresh temperate forages: a review. Animal Feed Science and Technology 106:3-19.

Miron, J.; Zuckerman, E.; Sadeh, D.; Adin, G.; Nikbachat, M.; Yosef, E.; Ben-Ghedalia, D.; Carmi, A.; Kipnis, T. and Solomon, R. 2005. Yield, composition and in vitro digestibility of new forage sorghum varieties and their ensilage characteristics. Animal Feed Science and Technology 120:17-32.

Montgomery, C. R.; Nelson, B. D.; Joost, R. and Mason, L. F. 1986. Tannin concentration and quality changes in sorghum as affected by maturity and sorghum type. Crop Science 26:372-375.

National Research Council - NRC. 1985. Nutrient requirements of sheep. 6th ed. National Academy Press, Washington, DC.

Neumann, M.; Restle, J.; Alves Filho, D. C.; Brondani, I. L.; Pellegrini, L. G. and Freitas, A. K. 2002. Avaliação do valor nutritivo da planta e da silagem de diferentes híbridos de sorgo (Sorghum bicolor, L. Moench). Revista Brasileira de Zootecnia 31:293-301.

Oliveira, S. G.; Berchielli, T. T.; Reis, R. A.; Vechetini, M. E. and Pedreira, M. S. 2009. Fermentative characteristics and aerobic stability of sorghum silages containing different tannin levels. Animal Feed Science and Technology 154:1-8.

Oliveira, S. G.; Berchielli, T. T.; Pedreira, M. S.; Primavesi, O.; Frighetto, R. and Lima, M. A. 2007. Effect of tannin levels in sorghum silage and concentrate supplementation on apparent digestibility and methane emission in beef cattle. Animal Feed Science and Technology 135:236-248.

Pedersen, J. F.; Gorz, H. J.; Haskins, F. A. and Ross, W. M. 1982. Variability for quality and agronomic traits in forage sorghum hybrids. Crop Science 22:853-856.
Pedreira, M. S.; Reis, R. A.; Berchielli, T. T.; Moreira, A. L. and Coan, R. M. 2003. Características agronômicas e composição química de oito híbridos de sorgo [Sorghum bicolor (L.) Moench]. Revista Brasileira de Zootecnia 32:1083-1092.

Rodriguez, M.; Borges, A. L. C. C.; Nogueira, F. S.; Gonçalves, L. C. and Borges, I. 1999. Silagem de sorgo de porte baixo, com diferentes teores de tanino e de umidade no colmo. IV- Influência dos taninos sobre a digestibilidade in vitro da matéria seca. Arquivo Brasileiro de Medicina Veterinária e Zootecnia, 51:577-582.

Rooney, W. L.; Blumenthal, J.; Bean, B. and Mullet, J. E. 2007. Designing sorghum as a dedicated bioenergy feedstock. Biofuels, Bioproducts and Biorefining 1:147-157.

Salawu, M. B.; Acamovic, T.; Stewart, C. S.; Hvelplund, T. and Weisbjerg, M. R. 1999. The use of tannins as silage additive: effect on silage composition and mobile bag disappearance of dry matter and protein. Animal Feed Science and Technology 82:243-259.

Satter, L. D.; Slyter, L. L. 1974. Effect of ammonia concentration on rumen microbial production in vitro. British Journal of Nutrition 32:199-208.

Schneider, B. H. and Flatt, W. P. 1975. The evaluation of feeds through digestibility experiments. University of Georgia Press, Athens.

Schofield, P.; Mbugua, D. M. and Pell, A. N. 2001. Analysis of condensed tannins: a review. Animal Feed Science and Technology 91:21-40.

Silanikove, N.; Perevolotsky, A. and Provenza, F. D. 2001. Use of tannin-binding chemicals to assay for tannins and their negative postingestive effects in ruminants. Animal Feed Science and Technology 91:69-81.

Stuart, P. 1984. Summer forage crops for silage. p.58-62. In: Silage in the 80 's. Kempton, T. J.; Kaiser, A. G.; and Trigg, T. E., eds. University of New England Press, Armidale.

Tilley, J. M. A. and Terry, R. A. 1963. A two stage technique for the in vitro digestion of forage crops. Journal of the British Grassland Society 18:104-111.

Van Soest, P. J. 1994. Nutritional ecology of the ruminant. 2nd ed. Cornell University Press, Ithaca, New York.

Van Soest, P. J.; Robertson, J. B. and Lewis, B. A. 1991. Official for dietary fibre, neutral detergent fibre and nonstarch polysaccharides in relation to animal nutrition. Journal Dairy Science 74:3583-3597.

Woodward, S. L.; Waghorn, G. C.; Ulyatt, M. J. and Lassey, K. R. 2001. Early indications that feeding lotus will reduce methane emissions from ruminants. p.23-26. In: Proceedings of the New Zealand Society of Animal Production. ACIAR, Adelaide. 